\title{
Appendicectomy; Non-Invaginaton Vs. Invagination of Appendicular Stump
}

M RAFI *M S ARSHAD S AHMAD RUHAQ

I) partme'n of Surger). Ma!o Hospital. \& * Sir. Ganga Ram Hospital. Lahore

(orrespondence to Di: Mazhar Rafi, Senior Registrar:

Objective: To find out the benefits of invagination of stump during appendicetomy. Acute appendicitis is the most common abdominal emergency requiring emergency surgery. Design: A prospective randomized clinical trail. Period: From June 2003 - May 2005. Setting: Mayo Hospital \& Sir Ganga Ram Hospital, Lahore. Patients \& methods: A prospective randomized study including 200 patients undergoing appendicectomy was carried out to see any advantage of invagination of appendicular stump. Results: A total of 200 operated cases of appendicitis divided in two groups of 100 cases each. In Group, a there were 59 males and to $2^{\text {nd }}$ and $3^{\text {rd }}$ decade. I Group there were 63 males and females. The youngest patient was 5 year old while the eldest was 57 year old. Maximum patients belonged to $2^{\text {nd }}$ and $3^{\text {rd }}$ decade. Conclusion: It was that there was no added benefit of invagination of appendicular stump, rather it took more operative time, and times, it was hazardous to do so.

Key word: Appendicitis, Operative technique, Comparison

Acute appendicitis remains the most common acute condition requiring acute abdominal surgery. First successful appendicectomy was performed in 1736. Appendicectomy was later described as a standard procedures by Charles McBurney'. Since then, acute appendicitis remain the most common condition requiring acute abdominal surgery. Obstruction of the lumen of the appendix is the principal cause, which may be due to lymphoid hypertrophy, fecolith, kinking or intestinal worms ${ }^{2}$. Both open and laparoscopy appendicectomy are being practiced ${ }^{(3)}$, but operating surgeon at times can not decide whether to invaginate the appendicular stump or not, and, moreover either procedure carry and advantage or not. The answer these questions, a prospective randomized study was done to compare to conventional appendicectomy techniques.

Patients and methods:

The study was designed as a prospective randomized clinical trail. Two hundred male and female patients of all ages operated for acute appendicitis from June 2003 to May 2005 in Mayo and Sir Ganga Ram Hospital, Lahore were included in the study. These patients were randomly divided in two equal groups. Appendicular stump of patients of Group-A were invaginated in the caecal wall, appendicular stump of patients of Group B were left as such. Cases of incidental appednicectomy, perforated appendicitis, appendicular mass and abscess were not included in this study. Detailed history regarding duration, onset, severity and shifting of abdominal pain was taken. Associated symptoms like nausea, vomiting, fever, any urinary or bowel disturbance were also recorded. Past history of any such attacks, was also taken, Thorough systemic clinical examination was conduced.

Diagnosis was based on tenderness and guarding in right lower quadrant of abdomen. Blood complete picture and time routine examination were done in every patient. Total and differential leucocytes and any urinary
$\mathrm{RBCs} / \mathrm{Pus}$ cells were also recovered. After proper preparation, all the patients were operated under preparation, all the patients were operated under general anesthesia. Abdomen was opened by transverse incision over the Mc Burnney's point. Location, size and nature of appendix were noted in each patient. After ligation of appendicular vessels, mesoappendix was divided Appendix was completely mobilized; chromic catgut No.1 A haemostat was applied close to ligature and appendix was divided with scalped and removed.

Appendicular stump patients of Group A invaginated in the caecum with a Purstring using $2 / 0$ chromic catgut on an atraumatic needle in $1 \mathrm{~cm}$ away from the appendicular stamp. On the other hand, appendicular stump of patients of Group B were left as such. Abdomen was closed in layers. None of the patient required drainage of abdominal cavity. Operative time was recovered in each case. It was taken from the start of incision to last skin suture. Every patient was given only three does of intravenous injection metronidezole first dose being the pre-operative one Injection diclofenac sodium $50 \mathrm{mg}$ deep intramuscular was given bid on first only. Post-operative vomiting and fever, if any, were noted. Oral fluids were started after 18 to 24 hours. Once flatus was passed and bowel sounds were audible. Operative site was examined on second and seventh post-operative day for any sign of infection, which was recorded. Skin sutures were removed on seventh postoperative day.

\section{Results:}

A total of 200 cases of acute appendicitis were reported. They were divided in two group of 100 cases each. In Group A, there were 59 males and 41 females. The youngest patient laws 5 years old while that eldest was 57 years old Maximum patients belonged to $2^{\text {nd }}$ and $3^{\text {rd }}$ decade. The age-wise distribution of patients is shown in Table I. Abdominal pain and nausea was a constant 
feature, while vomiting was present in 57\% of patients. Only 14 patients had dysuria. 71 percent of patients had classical presentation of shifting abdominal pain. Nine patients presented with recurrent attacks. Minimum duration of symptoms was 2 hours, while maximum was 14 days Minimum operating time was 20 minutes, while maximum was one hour mean being 40 minutes.

The maximum operating time was in a patient whose caecum along with appendix was lying in sub-hepatic position. Thirteen patients developed caecal haematoma while passing Z-suture to invert the appendicular stump. In eight patients caecum was edematous and it was difficult although possible to invaginate the appendicular stump. Three patients developed wound infection, all of them had gangrenous appendix with localized purulent peritoneal fluid.

In Group B, there were 63 males and 37 females. The youngest patient was 5 years old while the eldest was 57 years old. Maximum patients belonged to $2^{\text {nd }}$ and $3^{\text {rd }}$ decade. The age-wise distribution of patients is shown in Table-I. Abdominal pain and nausea was a constant feature $(100 \%)$, while vomiting was present in $66 \%$ of patients. Only 12 patients had dysuria. Seventy-four percent of patients had classical presentation of shifting abdominal pain. Sixteen patients presented with recurrent attacks.

Minimum duration of symptoms was 4 hours, while maximum was 11 days. Minimum operating time was 9 minutes while maximum was 30 minutes, mean being 14 minutes. The maximum operating time in two patients whose appendix was in sub-hepatic position. Two patients developed wound infection, both of them had purulent and friable appendix. The incidence of other complications is shown in Table II.

In both the group $40 \%$ of patients had total leukocytes count less than $10,000 / \mathrm{cm}$. Commonest position of appendix was retro caecal $(72 \%)$. Length of the appendix varied from $3 \mathrm{~cm}$ to $14 \mathrm{~cm}$, mean size was $6 \mathrm{~cm}$. Only two patients $(1 \%)$ in this study were pregnant at the time of surgery.

Table I: Age wise Distribution of Patients

\begin{tabular}{lll}
\hline Age in year & Group A & Group B \\
\hline $1-10$ & 7 & 8 \\
$11-20$ & 38 & 31 \\
$21-30$ & 38 & 35 \\
$31-40$ & 10 & 20 \\
$41-50$ & 6 & 5 \\
$51-60$ & 1 & 1 \\
\hline
\end{tabular}

Table II: Post Operative Complications.

\begin{tabular}{lll}
\hline Nature & Group A & Group B \\
\hline Vomiting & 23 & 21 \\
Fever & 17 & 19 \\
Wound infection & 3 & 2 \\
\hline
\end{tabular}

\section{Discussion:}

Acute appendicitis remain the commonest abdominal emergency and it affects $6-10 \%$ of population ${ }^{4}$. It may occur at any age but is most common in persons between 20 and 40 years of age ${ }^{5}$, as is observed in the present study. The diagnosis is most difficult in children under the age of 2 years and in the elderly patients ${ }^{6}$. Appendicitis is also the most common non-obstetric abdominal surgical emergency in pregnancy.

Anorexia and nausea were important symptoms in patients with appendicitis (100-5). Vomiting was variable in frequency and intensity (61.25). Tenderness and guarding in the rift lower quadrant was the single most important finding in acute appendicitis, and was the main diagnostic indictor ${ }^{8,9}$. The degree of muscle guarding varied considerably, Redound tenderness, direct and referred, depends upon the degree of involvement of the surface of the appendix and upon location of appendix. The customary laboratory tests of total and differential shown in the study done by khalid et $\mathrm{al}^{10}$.

Urinalysis was usually normal in patients with appendicitis ${ }^{11}$. Ultrasonography has got almost $100 \%$ diagnostic accuracy ${ }^{12}$. CT scan is more sensitive but is not cost effective ${ }^{13}$. Both these radiological modalities are helpful in children and elderly, who have atypical symptoms which can lead to delay in diagnosis. Appendicectomy remains the standard treatment of acute appendicitis, which is performed by both open and laparoscopic approaches ${ }^{14}$. Retrocaecal is the commonest position of the appendix; same was the case in my study $(72 \%)^{15}$.

Opinion is divided in literature over the value of invagination of appendicular stump with either a seromuscular purse-string suture or Z-stitch. Proponents of this procedure argue in favor of sound control of appendicular stump and less bacterial contamination of the peritoneal cavity ${ }^{16.17}$. On the other hand, opponents of appendicular invagiantion stress the potential hazard of: (i) injury/ damage to caecal blood supply, (ii) the procedure can be hazardous if the caeum is edematous/ friable ${ }^{18}$, and (iii) the development of stump abscess ${ }^{19,20}$. In my study there was no difference in the recovery and outcome of patients belonging to either group.

Post-operative fever (17 vs. 19) and vomiting (23 vs. 21 ) were almost equal in both the groups. Wound infection rate was also equal in both groups ( 3 in Group A vs. 2 in Group B), that too corresponded with the degree of appendicular inflammation. Moreover operating time was less in patients of Group B (mean 14 minutes) as compared to patients of Group A (mean 40 minutes).

With few exceptions the treatment of choice of acute appendicitis is appendicectomy. There is no added benefit of invaginating the appendiceal stump during appendicectomy. One can save time, and avoid certain potential complications by simple ligature of appendicular stump. 


\section{References:}

1. McBurnney C: Experience with early operative interference in case of disease of the vermiform appendix. NY State Med J 1889; 50: 676 .

2. Rosemary A K, Joel JR, The appendix. In: Schwartz SI, Shires GT, Spencer FC, Daly JM Fischer JE, Galloway AC eds. Principle of Surgery $7^{\text {th }}$ ed. McGraw Hill 1999; 1383()4.

3. McCahill LE, Pellegrini CA, Wiggins T, et al: Laparoscopic versus open appendiectomy: A prospective assessment. Br J Surg 1994; $81: 133$

4. Boswell CB. Doherty GM. Diseases of appendix. In. Doherty GM, Meko JB, Olson JA, Peplinski GR, Worral NK eds. The Washington Manual of Surgery $2^{\text {nd }}$ ed. Lippincott. Williams \& Wilkins 1999 Philadephia; 228:35.

5. Malik K, Ahmad W, Channa A, Khan A, Waheed I. Epidemiology of acute appendicitis: a study of 354 cases in Jinnah Postgraduate Medical Center, Karachi. The J Surg PIMS 1993:5:31-33.

6. Cuschicri A. The small intestine and vermiform appendix. In : Cuschierı A. Giles AR, Moosa AR eds. Essential Surgical Practice $3^{\text {rd }}$ ed. Butterworth Heinemann, Oxford 1995 New York; $1325-7$

7. Fallon WF, Newman JS, Fallon GL, et al: The surgical management of intra-abdominal inflammatory conditions during pregnancy. Surg Clin North Am 1995; 75:1

8. Bergeron E, Eicher B, Giarib R. Glard A. Appendicitis is a place for Clinical Judgement. Am J Surg 1999; 177: 460-2.

9. Syed AS, Abbas T. Appendicitis: still a clinical diagnosis. Pak J Surg 1995; $11(1): 22-25$.
10. Khalid K, Ahmad N, Farooq O, Anjum I, Sial GA. Acute appendicitis - Laboratory dependence can be misleading: Audit of 211 cases J Coll Physicians Surg Pakistan 2001; 11: 434-7.

11. Puskar D, Bedsalov G, Fridrib s, Vuckovic J, Banek T, Pasini J. Urinarlysis, ultrasound analysis and renal dynamic scintigraphy in acute appendicitis. Urology 1995; 15: 10812.

12. Gupta H, Dupuy DE, Advances in imaging of the acute abdomen. Surg Clin North Am 1997; 77; 1245-63.

13. Balthazar EJ, Eirnbaum BA, Yee J, et al: CT and and US correlation in 100 patients. J Radiol 1994; 190:31.

14. Scott-Conner $\mathrm{C}$ et al: Laproscopic appendectomy Ann Surg 1992; 215:660.

15. Guidry SP, Poople GV. The anatomy of appendicitis. Am Sur 1994; 60:68-71

16. Savage PEA. Appendicectomy. In, Dudley H ed. Rob \& Smith's Operative Surgery $4^{\text {th }}$ ed. Butterworths $1983 ; 373-9$.

17. Arnbjornsson E: Invagination of the appendiccal stump for the reduction of peritoncal bacterial contamınatıon. Curr Surg 1985; 42:184

18. Rintoul RF. Operations on the appendix. In. Rintoul RF ed Farquharson's Textbook of Operative Surgery $8^{\text {th }}$ ed. Churchill Livingstone NY 1995; 451-8.

19. Way, LW. Appendix. In. Way LW ed. Current Surgical Diagnosis \& Treatment $10^{\text {th }}$ ed. Appleton \& Lange 1994 New Jersey; 610-3.

20. Eills BW. Acute appendicitis. In. Ellis BW ed. Hamilton Bailey's Emergency Surgery $12^{\text {th }}$ ed. Butterworth Heinmann 1995. Cambridge; $411-3$. 